\title{
Cooperation and Accountability After the Feeney Amendment
}

\author{
Michael M. O'Hear \\ Marquette UniversityLaw School, michael.ohear@marquette.edu
}

Follow this and additional works at: http://scholarship.law.marquette.edu/facpub

Part of the Law Commons

Publication Information

Published as Michael M. O'Hear, Cooperation and Accountability After the Feeney Amendment, 16 Fed. Sent'g Rep. 102 (2003). () 2003 by the Regents of the University of California on behalf of the Vera Institute of Justice. Copying and permissions notice: Authorization to copy this content beyond fair use (as specified in Sections 107 and 108 of the U. S. Copyright Law) for internal or personal use, or the internal or personal use of specific clients, is granted by the Regents of the University of California on behalf of the Vera Institute of Justice for libraries and other users, provided that they are registered with and pay the specified fee via Rightslink ${ }^{\oplus}$ on Caliber (http://caliber.ucpress.net/) or directly with the Copyright Clearance Center, http://www.copyright.com.

\section{Repository Citation}

O'Hear, Michael M., "Cooperation and Accountability After the Feeney Amendment" (2003). Faculty Publications. Paper 107. http://scholarship.law.marquette.edu/facpub/107

This Article is brought to you for free and open access by the Faculty Scholarship at Marquette Law Scholarly Commons. It has been accepted for inclusion in Faculty Publications by an authorized administrator of Marquette Law Scholarly Commons. For more information, please contact 


\section{Cooperation and Accountability After the Feeney Amendment}

\section{$\lim _{\infty}^{\infty}$ \\ MICHAEL M. O'HEAR}

Assistant Professor, Marquette University Law School.
The federal sentencing guidelines are designed to encourage defendants to cooperate with law enforcement authorities. "Cooperation," in this context, means not only providing assistance in the apprehension and prosecution of other criminal offenders, but also such other desirable actions as pleading guilty before trial. The guidelines induce cooperation through a variety of authorized adjustments and departures, including provisions rewarding substantial assistance and acceptance of responsibility, and penalizing obstruction of justice ${ }^{1}$

Neglected amidst other controversial provisions, Congress through the Feeney Amendment accomplished the most important restructuring of cooperation inducements in the federal system since the guidelines' promulgation. In particular, Congress legitimized and attempted to impose new controls over locally-initiated early disposition programs, while shifting some judicial power over the acceptance of responsi bility adjustment to prosecutors.

In this Article, I describe the guidelines' system for inducing cooperation before and after Feeney. I also offer a preliminary evaluation of the changes Feeney has wrought, including the policy decisions made by the Sentencing Commission and the Attorney General for purposes of implementing the new early disposition departure.

I focus here, in particular, on problems of public accountability. PreFeeney, the cooperation inducement regime left considerable discretion in the hands of sentencing judges, United States Attorneys, and line prosecutors, resulting in much district-to-district variation in sentencing practices. Localized decisionmaking, in and of itseff, may not necessarily be a bad thing - indeed, I believe it is affirmatively desirable but localization was accomplished preFeeney with little public explanation or review. The lack of accountability gave rise to charges that the cooperation inducements were being used disingenuously to underminethe efforts of Congress and the Commission to increase sentence lengths. The Feeney Amendment seems to address some of these accountability concerns through the new early disposition departure. At the same time, the increasingly preeminent role of prosecutors raises new accountability concerns in its own right.

\section{Cooperation Before Feeney}

\section{A. Relevant Guidelines}

The guidelines encourage cooperation primarily through the substantial assistance and acceptance of responsibility provisions. Under $\S 5 K 11$, the sentencing judge may depart downward "upon motion of the government stating that the defendant has provided substantial assistance in the investigation and prosecution of another person who has committed an offense." The various U nited States Attorneys' Offices ("USAOs") have interpreted and applied the provision differently. They disagree, for instance, over whether a defendant may earn a substantial assistance motion merely by providing information as to his or her own criminal activity. In some districts, substantial assistance departures have become routine, while in others they are rare. ${ }^{3}$

Under $\S 3 E 11$, the sentencing judge may reducea defendant's offense level by two points if the defendant "clearly demonstrates acceptance of responsibility for his offense." This provision grew out of the Commission's desire to provide an incentive for defendants to plead guilty, ${ }_{1}^{4}$ and, in many districts, judges seem to award an acceptance adjustment on a nearly automatic basis to defendants who do so. ${ }^{5}$

In 1992, the Commission amended $\S$ 3E11 to allow judges to reduce the defendant's offense level by a third point if the defendant's offense level is 16 or greater (before applying any acceptance adjustment) and the defendant "assist[s] authorities in the investigation or prosecution of his own misconduct." A defendant might satisfy the latter requirement either by (1) "timely providing complete information to the government concerning his own involvement in the offense" or (2) "timely notifying authorities of his intention to enter a plea of guilty." The amendment was intended to provide defendants with a greater incentive to plead guilty than had been avail able when judges could only award a two-point discount. ${ }^{6}$

While the substantial assistance and acceptance provisions are the most frequently invoked, other sections of the guidelines al so encourage cooperation, such as the penalties for obstruction of justice and reckless endangerment during flight from a law

Federal Sentencing Reporter, Vol. 16, No. 2, pp. 102-108, ISSN 1063-9867, electronic ISSN 1533-8363. ๔ 2004 Vera Institute of Justice. All rights reserved. Send requests for permission to reprint to: Rights and Permissions, University of California Press, Journals Division, 2000 Center Street, Suite 303, Berkeley, CA 94704-1223. 
enforcement officer. ${ }^{7}$ I have argued elsewhere that the Commission ought to rethink the relationship among the disparate cooperation-inducing provisions, with an eye to addressing various inconsistencies and redundancies. ${ }^{8}$

B. Cooperation Inducements Outside the Guidelines While the guidelines offer cooperation inducements, many prosecutors found the guidelines regime too rigid or parsimonious, and resorted to other mechanisms to induce cooperation. Thus, for instance, various southwest border districts adopted early disposition, or "fast-track," programs; under these programs, prosecutors would agree to support non-substantial-assistance departures as an inducement to very quick pleas on standardized terms. ${ }^{9}$ In other districts, prosecutors would charge-bargain in order to induce early pleas. ${ }^{10}$ Prosecutors felt that the special plea inducements were necessary, in particular, to process a growing tide of immigration cases. Thus, for instance, the fast-track program in the Southern District of California facilitated a six-fold increase in annual prosecutions of criminal alien cases between 1994 and $2001^{11}$

Yet, the fast-track programs were of questionable validity, particularly insofar as they required prosecutors to make departure motions or support other sentencing benefits not clearly justified by the law or the facts. ${ }^{12}$ Moreover, they at least arguably contravened the spirit of the guidelines, which explicitly provided for acceptance and substantial assistance as the approved means of inducing cooperation.

Although the legal authority for some fast-track programs was uncertain pre-Feeney, they existed in as many as half of the nation's judicial districts. ${ }^{13}$ H owever, because fast-track benefits were not required to be reported as such to the Commission, their magnitude and frequency were not precisely known.

\section{Cooperation After Feeney}

\section{A. Statutory Changes}

With respect to cooperation, the Feeney Amendment's most notable contribution is the creation of a new four-level "downward departure" for defendants who plead guilty pursuant to an authorized early disposition program. ${ }^{14}$ The early disposition departure seems to fill an important gap in the guidelines by providing an explicit, incremental incentive for defendants who plead even earlier, and under conditions even more favorable to the government, than is required for an acceptance adjustment.

While early disposition programs are not new, Feeney nonetheless marks a watershed in their development. In part, this is because early departure programs have now been legally legitimized, and might thus spread to new districts or take on new forms. But, at the same time, the Feeney Amendment also brings early disposition programs under greater central control: Congress has limited the sentencing discount to four levels, and early disposition programs now require the Attorney General's authorization. Such restrictions may offset the legitimization effects, and perhaps lead to a contraction in the number of early disposition programs.

In addition to establishing the new early disposition departure, the Feeney Amendment also modifies $\S 3$ E11 by requiring a prosecutor's motion before the sentencing court can award the third level of the adjustment. ${ }^{15}$ The change has been made, according to the new law, "[b]ecause the Government is in the best position to determine whether the defendant has assisted authorities in a manner that avoids preparing for trial."16

Additionally, in order to qualify for the third-level reduction, the defendant must now timely notify the government of his or her intention to plead guilty. The Feeney Amendment strikes previous language that allowed a three-level reduction merely for timely providing information to the government, without necessarily entering a timely plea. ${ }^{17}$ Thus, at the same timethat greater control over acceptance has been shifted to the prosecutor, the grounds for receiving an extra onelevel reduction based on acceptance of responsibility have been narrowed.

The Feeney Amendment leaves substantial assistance and other cooperation provisions largely untouched. ${ }^{18}$

\section{B. Implementation of the Fast-Track Provision}

\section{Guideline Amendment}

In order to implement the provision in the Feeney Amendment authorizing an official "fast-track" departure, the Commission promulgated new $\S 5 \mathrm{~K} 3.1$, which largely tracks the statutory language in authorizing a downward departure of not more than four levels. Departure requires a motion from the government made pursuant to an authorized early disposition program. The Commission provided no additional guidance for the new departure. For instance, while the Commission suggested that the sentencing court will have discretion in deciding whether to grant a departure ("the court maydepart"), the Commission did not provide a standard to govern this exercise of discretion. Nor did the Commission suggest any circumstances in which the court might appropriately deny a government motion. Likewise, other than capping the departure at four levels, the Commission did not offer any guidance as to the proper scope of departure.

\section{Attorney General Memorandum}

The Attorney General offered his own set of implementation principles for "fast-track" departures in his memorandum to all U.S. Attorneys dated September 22, 2003 (the "Fast Track Memo"). ${ }^{19}$ Pursuant to the Memo, in order to obtain authorization to operate an early disposition program, a U.S. Attorney's Office (USAO) must demonstrate that: 
(A) (1) the district confronts an exceptional ly large number of a specific class of offenses within the district, and failure to handle such cases on an expedited of "fast-track" basis would significantly strain prosecutorial and judicial resources available in the district; or (2) the district confronts some other exceptional local circumstance with respect to a specific class of cases that justifies expedited disposition of such cases;

(B) declination of such cases in favor of state prosecution is either unavailable or clearly unwarranted;

(C) the specific class of cases consists of ones that are highly repetitive and present substantially similar fact scenarios; and

(D) the cases do not involve an offense that has been designated by the Attorney General as a "crime of violence."20

The Memo also identifies certain features that will be required of all authorized early disposition programs. In order to qual ify for departure, for instance, the defendant will have to plead guilty "within a reasonably prompt period after the filing of federal charges." ${ }^{21}$ Additionally, the defendant must agree to a factual basis that accurately reflects the offense conduct, and must also waive Rule 12(b)(3) motions, appeals, and § 2255 challenges. ${ }^{22}$

Some matters are left to the discretion of the USAOs. For instance, each qualifying USAO may determine the magnitude of the departure (up to four levels), or choose to leave the question to the sentencing judge ${ }^{23}$ Alternatively, theUSAO may employ charge-bargaining in its fast-track program, so long as the resulting sentence reductions are "commensurate with" the authorized downward departure ${ }^{24}$

\section{Evaluation}

In this Part, I offer a preliminary evaluation of the Feeney Amendment reforms based on four overlapping considerations: overall coherence of the cooperation inducement regime, localization in federal sentencing, accountability, and prosecutorial power.

\section{A. Coherence}

A coherent system of cooperation inducements should provide graduated benefits al ong a spectrum of cooperative behaviors, from the eve-of-trial change of plea to assisting authorities in the apprehension of other criminals. In some respects, the Feeney Amendment does enhance coherence in this area. Most importantly, the new early disposition departure fills an important gap in the guidelines structure, providing incremental benefits for defendants whose early guilty pleas far exceed the minimal requirements for acceptance of responsibility, but who are not able to provide substantial assistance. The Feeney Amendment recognizes that not all plea deals are created equal: by their timing, for instance, or the scope of their waivers, some deals may be much more beneficial to the government than others. While this point was already recognized in the third level of the acceptance adjustment, the incremental benefit was limited to defendants with an offense level of at least 16 and was not, in any event, an especial ly large benefit. The importance of the gap is perhaps best demonstrated by the fact that as many as half of all districts had developed fast-track programs prior to the Feeney Amendment.

At the same time, the gap-filling benefits are subject to several important constraints. The early-disposition departure will not necessarily be available in all districts. Where it is avai lable, it will be limited to a designated class of cases. The Attorney General's minimum requirements further diminish the flexibility of the cooperation inducement. Meanwhile, the unguided discretion of the sentencing court in awarding early disposition departures may undermine the certainty (and, hence, attractiveness) of the sentencing benefit for defendants. In short, the early-disposition departure is only a first step towards the sort of flexible, broadly applicable adjustment that is needed for defendants who go beyond mere acceptance of responsibility, but who do not qualify for a departure based on substantial assistance.

Indeed, in other respects, the Feeney Amendment exacerbates incoherence. In particular, the Amendment eliminates the timely provision of information as a basis for awarding a third-level reduction for acceptance of responsibility. Sentencing benefits here (much as with the early-disposition departure) thus turn principally on the timing of a plea agreement. Yet, timely providing information may carry much the same benefits in reducing trial preparation as a timely plea, as well as additional public benefits in some cases (e.g., exonerating innocent co-defendants, helping the authorities to recover stolen goods or dangerous contraband, giving the public information that might help to prevent similar crimes in the future). Thetimely provision of information seems an appropriate form of cooperation to reward, even if not accompanied by a timely plea (which may be due to dilatory or unreasonable negotiation tactics by the prosecutor). The elimination of this possibility - coupled with the new requirement of a government motion for the third-level reduction for acceptance of responsibility - renders $\S 3 E 1$ leven more rigid and less helpful as a cooperation inducement tool than it was before the Feeney Amendment.

\section{B. Localization}

I have argued elsewhere that the Commission and the federal appel late courts have placed unnecessary and 
inappropriate restrictions on local variation in sentencing. ${ }^{25}$ Within certain bounds, sentencing judges and USAOs should have the freedom to adapt national sentencing norms to local needs and preferences.$^{26}$ Indeed, at the time that the Sentencing Commission was created, Congress itself suggested that local variation might appropriately be incorporated into the guidelines regime. Congress expressly required the Commission to consider the relevance of "the community view of the gravity of the offense" and "the current incidence of the offense in the community."27

While the Commission has not formally endorsed local variation in sentencing, a considerable body of evidence indicates that such variation has become pervasive ${ }^{28}$ Professors Frank Bowman and Michael Heise, drawing on an analysis of drug sentencing patterns over the last 10 years, suggest that, "in place of a single uniform national sentencing system, the guidelines have created a network of separate local and regional systems," in each of which the front-line sentencing actors have established a distinct "equilibrium" as to "the commonly occurring issues in guidelines application."29

In the absence of clear authorization or structure, current patterns of local variation raise important concerns. In particular, insofar as local variation arises from plea-bargaining (and hence does not create the sort of record that would be generated by an adversarial process), such variation evades public scrutiny and debate, as well as review by appellate courts and the Sentencing Commission. Simply put, the benefits of localization must be balanced with a need for accountability.

The early disposition departure may be a step in the right direction. With this provision, the Feeney Amendment provides the clearest legal authorization yet for tailoring local sentencing practices to local needs. Yet, the Feeney Amendment also imposes a structure on, and enhances accountability for, local ization. Departures are limited to four levels. Early disposition programs must be authorized by the United States Attorney and the Attorney General. This authorization process may draw localization more into the open, where it can be better scrutinized and commented on by the public, the Commission, and the legislature.

At the same time, the Attorney General has perhaps been unduly restrictive in the criteria adopted for early disposition programs. For instance, the Fast Track Memo suggests that such programs should be limited to "exceptional circumstances," ${ }^{30}$ although the statute contains no such limitation. Of course, this and other criteria are hardly self-defining. (When is declination "clearly unwarranted"? What does it mean for a class of cases to be "highly repetitive"?) In practice, the criteria may be implemented in ways that are more or less restrictive.
If the criteria are interpreted broadly, authorized early disposition programs may become commonplace, thus enhancing localization in federal sentencing. If the criteria are interpreted narrowly, however, local ization may be suppressed or remain in the shadows. This would be an unfortunate outcome- another missed opportunity to bring localization into the guidelines structure, akin to the Sentencing Commission's failure to seize Congress's invitation to take community views and circumstances into account in drafting the guidelines.

\section{Accountability}

The Feeney Amendment requires greater accountability of fast-track programs. They have become subject to a structure created by Congress and the Attorney General. They must be justified based on general criteria. They are subject to review by the Attorney General. Cases disposed of pursuant to a fast-track program must be reported as such. ${ }^{31}$ These sorts of reforms lend greater legitimacy to the fast track.

Yet, from an accountability standpoint, the Fast Track Memo leaves several crucial matters unaddressed. First, the procedures specified in the Memo do not provide for public notice and comment on fast-track proposals. Second, the procedures permit USAO proposals, but do not provide for proposals from other stakeholders. I mportantly, while the statutory provisions of the Feeney Amendment require USAO authorization for fast-track programs, the statute does not indicate that such programs must be initiated by a USAO. If others stakeholders (eg., judges, public defender organizations, state and local law enforcement) could initiate proposals, then USAOs could be drawn into a dialogue about the appropriateness of fast-track programs for their districts. As it is, it appears that, if the local USAO declines to propose a fast-track program (whether for bureaucratic intransigence or otherwise), other stakeholders and the public simply have no recourse. Put differently, the Fast Track Memo imposes new accountability on the decision to implement a fast-track program, but no accountability for the decision not to implement such a program.

Third, the Fast Track Memo does not provide for review of a fast-track program after it is initially authorized. Thus, a program may seemingly operate indefinitely after winning approval, even though the underlying circumstances justifying the program may change. For instance, a drug-related crime wave in a district may be an appropriate basis for a fast-track program for drug defendants, but there is no mechanism in place that would ensure reconsideration of the program once the crime wave ends. A regular reauthorization process (say, once every three years) would help to ensure that programs continue to be justified. Public notice and comment opportunities would further enhance accountability in the reauthorization process. 
Likewise, the Sentencing Commission has perhaps diminished the accountability envisioned by Congress in the way that it has chosen to implement the early disposition departure. New $\S 5 K 3.1$ simply instructs the sentencing court that it "may depart downward not more than 4 levels" upon motion of the government. The decision whether to depart, and how much to depart, seems entirely up to the court, without any particular standard to guide the district court's discretion or subsequent appellate review. May a judge deny a motion based on the judge's belief that the resulting sentence would not be commensurate with the seriousness of the offense? May a judge override a prosecutor's recommendation for, say, a two-level departure and award the full four levels because the judge believes the sentence would otherwise be unduly harsh to the defendant and her family? May a judge deny a motion because the judge disagrees with the underlying decision to create a fast-track program? Based simply on the text of $\S 5 K 3.1$, the answer to all of these questions is, at least arguably, yes. Yet, to the extent this interpretation is correct, $\S 5 \mathrm{~K} 3.1$ could become a license for individual judges to override the policy judgments of Congress, the Commission, and the Department of Justice.

The Commission would have done better to specify that a $\S 5 \mathrm{~K} 3$.1 motion should be granted so long as the defendant has complied with the terms of the district's authorized early disposition program. As to calculating the magnitude of the departure, this should not be viewed as an opportunity to reopen questions of offense severity and the like, but, rather, as in inquiry into the value of the defendant's cooperation. Because prosecutors are in the best position to assess the value of an early disposition, their recommendations should be given weight, perhaps even a rebuttable presumption of correctness, but sentencing courts might al so be instructed to consider the $\S 5 \mathrm{~K} 11$ and $\S 3 \mathrm{E} 11$ jurisprudence on substantial assistance and acceptance of responsibility as establishing benchmarks for how much to reward cooperation. Additionally, sentencing courts should be given responsibility for softening prosecutor-to-prosecutor disparities that may arise in implementing an early disposition program. If one prosecutor routinely makes $\S 5 \mathrm{~K} 3$.1 motions in cases that would otherwise generally not receive early disposition treatment in the district, the judge might consider awarding only a small benefit (say, a one-level departure). If another prosecutor routinely recommended onlya small benefit in cases that would otherwise typically result in more generous recommendations, the judge might take that fact into account as well.

\section{Prosecutorial Power}

Rewarding cooperation presents a difficult procedural dilemma: who should control the distribution of sentencing benefits. On the one hand, the prosecutor is in the best position to know the scope and importance of the defendant's cooperation. The prosecutor understands what effort has been expended on the case, and how the defendant's behavior has either facilitated or impeded an efficient resolution. The prosecutor knows the usefulness of any assistance the defendant has offered towards the prosecution of other offenders. The prosecutor knows whether the defendant has been honest in her dealings with the authorities. All of this suggests that the prosecutor ought to control how much of a cooperation benefit the defendant receives at sentencing. Moreover, to the extent that the prosecutor bargains for cooperation, the prosecutor will be able to bargain most effectively if the defendant knows that the prosecutor will be able to deliver whatever cooperation benefits are promised.

On the other hand, there are equally persuasive arguments that the judge ought to control the distribution of cooperation benefits. Judicial decisions are subject to important procedural safeguards that do not apply to prosecutorial decisions: judges make decisions on the basis of evidence that is subject to adversarial testing, judges must publicly explain their decisions, and judges may be reversed by an appellate court. Prosecutors, in short, are less accountable for their decisions than judges. Additionally, because prosecutors are the primary beneficiaries of defendant cooperation, prosecutors may not be the most trustworthy eval uators of cooperation. They may tend to val ue cooperation too high relative to other purposes of sentencing, such as ensuring that punishment is proportionate to culpability. They may al so value some forms of cooperation that are at least arguably contrary to the public interest. For instance, while a prosecutor might be inclined to reduce or deny cooperation benefits for the filing of any pretrial motion, regardless of the merits, a judge might properly be reluctant to penalize a defendant for making a colorable constitutional claim.

Before the passage of the Feeney Amendment, the guidel ines divided the authority to reward cooperation between judges and prosecutors. Prosecutors held (and still hold) the keys to the substantial assistance departure, but exercised much less control over the award of downward adjustments for acceptance of responsibility. The Feeney Amendment modifies the balance of power by giving prosecutors, in effect, an essentially unreviewable veto over the award of the third-level acceptance reduction. The Feeney Amendment likewise makes prosecutors the gatekeepers to the new early disposition departure by conditioning the departure on a government motion.

This readjustment of power seems an odd move in a piece of legislation that otherwise seeks to reduce the discretion and enhance the accountability of front-line sentencing actors. ${ }^{32}$ Of particular concern is the absence of a mechanism to review refusals to make acceptance of responsibility and early disposition departure motions. 
The lack of such a mechanism invites unwarranted disparities in implementation, reflecting different approaches to plea-bargaining by different prosecutors in different cases. The availability of a prosecutor's motion in a given case may turn on any number of considerations that smack of arbitrariness: the prosecutor's relationship with defense counsel; whether the prosecutor's attention is absorbed by other cases; the prosecutor's desire for trial experience or a reputation for toughness; race, ethnicity, or sex discrimination (conscious or otherwise); and so forth. Indeed, past experience with substantial assistance motions - for which some correlation has been found with various personal demographic characteristics, such as sexand ethnicity ${ }^{33}$ - suggests that these concerns are more than merely speculative.

The concerns here may be addressed at two levels. First, the sentencing judge may correct arbitrary refusals to make a motion. I ndeed, there seems no good reason why judges should not have at least the same (very limited) authority in this context that they have to review improper refusals by prosecutors to offer substantial assistance motions. ${ }^{34}$ Still, this sort of review seems unlikely to provide a systematic check on prosecutorial arbitrariness: cooperation motions are necessarily wrapped up in the plea-bargaining process, which courts have been loathe to intrude upon in light of separation of powers concerns.

Second, the USAO may adopt policies and procedures that minimize disparities. For instance, the USAO may set forth clear, written criteria that establish under what circumstances a motion will be made. Thus, for an early disposition program, the USAO might precisely define what cases are subject to the program, what sort of plea offer must be tendered to eligible defendants by when, and how long defendants have to accept or reject the offer. Assuming all of these conditions are satisfied, the prosecutor would be obligated to make a $\S 5 \mathrm{~K} 3.1$ motion. Alternatively (or additionally), the USAO might establish internal review procedures, permitting defendants to "appeal" refusals to make a cooperation motion and requiring a written explanation of the disposition of the appeal.

It is unfortunate that these sorts of considerations were not addressed in the Fast Track Memo. For instance, specific internal review procedures might have been required as a condition of approval for an early disposition program. Even now, in responding to proposals, the Attorney General might at least encourage USAOs to adopt policies and procedures that will allay concerns about prosecutorial inconsistency. Yet, the Department of J ustice's historic failure to address concerns regarding substantial assistance motions leaves one with little confidence that the new responsibilities of federal prosecutors will be administered with any more effective internal controls.

\section{Conclusion}

Before the Feeney Amendment was enacted, the guidelines suffered from a substantial gap in the cooperation inducement regime, with no clearly authorized bases for rewarding cooperation going beyond mere acceptance of responsibility, but not rising to the level of substantial assistance. In order to fill this gap, many districts developed fast-track programs that at least arguably contravened the spirit of the guidelines.

Congress responded appropriately by authorizing the new early disposition departure. This departure fills an important gap in the guidelines and offers enhanced accountability (and hence legitimacy) to fast-track programs. One might object by arguing that cooperation should not be part of the sentencing calculus at all, but cooperation inducements have been part of the guidelines from the beginning and are otherwise well-ensconced in the American criminal justice system. ${ }^{35}$ The only realistic question is how much of an inducement for what types of cooperation. If we are going to have cooperation inducements, we ought to have a coherent system that makes justifiable distinctions among defendants on justifiable grounds. The early disposition departure is a step in the right direction towards a more coherent system.

The early disposition departure also brings new flexibility to the guidelines by explicitly authorizing sentencing variation based on local conditions. Formal recognition of localization is long overdue in federal sentencing law. Of course, de facto localization has been a continuing reality of federal sentencing practice It is time for the law to catch up with the practice. A disconnect between the two has undermined public confidence in the system, fueling the perception of lawlessness in sentencing that drove the enactment of many of the less appealing aspects of the Feeney Amendment. Much like cooperation inducements, localization is a fact of life for contemporary criminal justice; the real challenge with both is to develop a coherent, structured system that offers both flexibility to front-line sentencing actors and assurances of accountability to the public. It is to be hoped that the early disposition departure will promote a new dialogue about "structured localization" and ultimately lead to additional reforms along these lines.

Yet, the promise of the early disposition departure may be undermined by two other developments. First, the Attorney General may unduly restrict the availability of the departure. While it is not yet clear how the criteria set forth in the Fast Track Memo will be implemented, the emphasis on "extraordinary circumstances" suggests that the Attorney General intends to reduce the prevalence of fast-track programs. If USAOs are discouraged from developing fast-track proposals, then the dialogue on structured localization may end up stunted and ineffective. 
Second, the Feeney Amendment's emphasis on prosecutorial control, coupled with the implementation policy decisions made by the Attorney General and the Sentencing Commission, may result in as much confusion and frustration with the new cooperation regime as with the old. The statute gives an unreviewable veto to prosecutors over both the early disposition departure and the third-level reduction for acceptance of responsibility. The Commission gave no guidance to help sentencing judges review the early disposition recommendations made by prosecutors. The Attorney General did not provide for robust public participation in the early departure program. Where the old cooperation regime could rightly be criticized for a lack of accountability, the new regime may suffer much the same weakness, but with frustration now focused not on the supposedly softhearted federal judges, but on the opaque prosecutorial bureaucracy.

\section{Notes}

1 See U.S.S.G. $\S 5 \mathrm{~K} 1.1$ (substantial assistance), $\S 3 \mathrm{E} 1.1$ (acceptance of responsibility), $\S 3 \mathrm{Cl} 1$ (obstruction of justice).

2 See linda Drazga Maxfield \& J ohn H. Kramer, U.S. Sentencing Comm'n, Substantial Assistance: An Empirical Yardstick Gauging Equity in Current Federal Policy and Practice 9 (1998).

3 See Michael M. O'Hear, National Uniformity/ Local Uniformity: Reconsidering the Use of Departures to Reduce Federal-State Sentencing Disparities, 87 IOWA L. ReV. 721 , 747 (2002) [hereinafter O'Hear, National Uniformity].

4 See Michael M. O'Hear, Remorse, Cooperation, and "Acceptance of Responsibility": The Structure, Implementation, and Reform of Section 3E1.1 of the Federal Sentencing Guidelines, 91 NoRthwestern L. ReV. 1507, 1512-14 (1997) [hereinafter O'Hear, Remorse].

5 See id. at 1534.

6 See id. at 1516 n.34.

See U.S.S.G. $\S 3$ C1.1 (obstruction of justice), $\S 3 C 1.2$ (reckless endangerment).

8 See O'Hear, Remorse, supra note 4, at 1571-72.

9 See United States Sentencing Commission, Report to Congress: Downward Departures From the Federal Sentencing Guidelines 63 (2003) [hereinafter USSC DEPARTURE REPORT].

10 See id. at 65.

11 Vanessa Blum, Ashcroft Memo Endorses Plan for Swift Pleas, LegAl TImes, Oct. 2, 2003.

12 The Feeney Amendment itself directs the Attorney General to take steps to ensure that Department of J ustice attorneys oppose downward departures that are not supported by the law or the facts. See PROTECT Act, $\S 401(I)(1)(A)$.
13 See USSC Departure Report, supra note 9, at 64.

14 See PROTECT Act, $\S$ 401(m)(2)(B).

15 See PROTECT Act, $\S 401(\mathrm{~g})(1)(\mathrm{A})$.

16 PROTECT Act, $\S 401(\mathrm{~g})(2)(\mathrm{B})$.

17 See PROTECT Act, $\S$ 401(g)(1)(B).

18 For child abduction and sexual offenses, however, the Amendment does preclude a substantial assistance departure unless the sentencing court finds that the defendant's substantial assistance "established a mitigating circumstance of a kind, or to a degree, not adequately taken into consideration by the Sentencing Commission in formulating the guidelines that should result in a sentence lower than that described." See PROTECT Act, $\S$ 401(a)(1). In short, it appears that the sentencing court must make special additional findings in cases involving child abduction and sexual offenses, which may reduce the frequency of substantial assistance departures in cases involving the specified offenses.

19 Memorandum From Attorney General J ohn Ashcroft, United States Department of J ustice, to All United States Attorneys (September 22, 2003) [hereinafter Fast Track Memo] reprinted infra 16 Fed. Sent. Rep 134 (2003).

20 Id. at 2

21 Id.

22 See id. at 3. An exception to the $\S 2255$ waiver is permitted for claims of ineffective assistance of counsel.

23 See id.

24 Id.

25 See O'Hear, National Uniformity, supra note 3, at 739-44, 753-67.

26 As J udge Broderick once observed in these pages: Possession of a firearm by a felon will be viewed markedly differently in Wyoming, where hunting is a way of life, and in the South Bronx, where a felon with a firearm is a threat to the community. Other things being equal, one would expect the citizenry of [Wyoming] ... to be much more tolerant of the weapons violator than would the New Yorker.

Vincent L. Broderick, Local Factors in Sentencing, 5 Fed. Sent. REP. 314, 314 (1993).

2728 U.S.C. $\S 994(c)(4),(7)$.

28 For a summary of some of this evidence, see O'Hear, National Uniformity, supra note 3 , at 744-47.

29 Frank O. Bowman III \& Michael Heise, Quiet Rebellion? Explaining Nearly a Decade of Declining Federal Drug Sentences, 86 lowa L. Rev. 1043, 1135 (2001).

30 Fast Track Memo, supra note 19 , at 1.

31 See id. at 4

32 For example, the Feeney Amendment requires the Attorney General to address Guidelines circumvention by line prosecutors, see PROTECT Act, $\S 401(\mathrm{I})(1)(\mathrm{A})$, and requires a higher standard of appellate review of sentencing decisions, see PROTECT Act, $\S$ 401(d)(2).

33 MAXFIELD \& KRAMER, supra note 2, at 15.

34 See Wade v. United States, 504 U.S. 181 (1992).

35 For an argument that plea inducements are unavoidable, see O'Hear, Remorse, supra note 4, at 1566-68. 